NOTE

\title{
First record of Holocentrus ascensionis (Osbeck, 1765) (Osteichthyes: Holocentridae) in the Canary Islands (Central-east Atlantic)*
}

\author{
JOSÉ J. CASTRO-HERNÁNDEZ and ANA Y. MARTÍN-GUTIÉRREZ \\ Departamento de Biología, Universidad de Las Palmas de Gran Canaria, Apdo. 550, Canary Islands, Spain.
}

\begin{abstract}
SUMMARY: The capture of a specimen of Holocentrus ascensionis (Osbeck, 1765), a species previously unrecorded in the Eastern Atlantic north of Gabon, is reported from Gran Canaria Island (Canary Islands, Central-East Atlantic).
\end{abstract}

Key words: Holocentrus ascensionis; Central-East Atlantic, Canary Islands.

In February 1999 a specimen of Holocentrus ascensionis was fished off the south-east coast of Gran Canaria Island (Canary Islands). The fish was caught using a trap (Hernández-García et al., 1998) located over the sea bottom at $35 \mathrm{~m}$ depth. The squirrelfish was housed in a 100-1 glass aquarium for nine days in order to check its taxonomical status and to observe its behaviour in the tank. In the Eastern Atlantic, the presence of this species has been previously reported in St. Helena and Ascension Islands and from Angola and Gabon (Greenfield, 1981; Ben-Tuvia, 1990). This is the first time that it has been recorded north of the equator, and as a member of the ichthyofauna of the Canary Islands $\left(28^{\circ} \mathrm{N}\right)$.

The fish was $205.0 \mathrm{~mm}$ of total length (Table I). The distinctive characters agreed with those given by Greenfield (1981). The body moderately compressed (the standard length/height ratio was 3.06), relatively slender and oblong. The caudal peduncle

\footnotetext{
*Received April 14, 1999. Accepted June 29, 1999
}

was slender and long. Edges of membrane bones of head were serrate and spiny. Three conspicuous strong spines on the side of the head ( 2 opercular spines and a preopercular one). The upper opercular spine twice size of the lower opercular one. These two opercular spines clearly shorter than the preopercular one. Upper jaw was long, extending beyond posterior margin of pupil. Anterior portion of the dorsal fin had 11 spines and the posterior portion of this fin had 16 soft rays. A posterior soft dorsal fin 1.75 times higher than the anterior portion of the dorsal fin (this aspect is not well drawn in Greenfield, 1981). The anal fin with 4 spines (the first very small and almost inlaid in the body) was followed by 10 soft rays (Fig. 1). Fifty one scales in the lateral-line.

During housing in the aquarium, the color of the back and upper sides was reddish (or orange) with golden reflections (Fig. 1). It showed two dark greenish stripes following scales intersections on upper sides, fading posteriorly. The nine stripes below these were less distinct, pink to white near the 


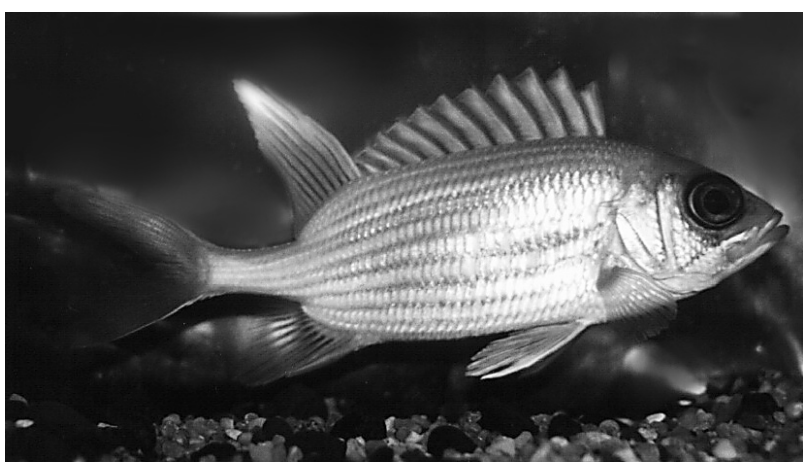

FIG. 1. - Holocentrus ascensionis, $205.0 \mathrm{~mm}$ total length, caught off Gran Canaria Island.

belly, when the fish was calm. When the fish was excited or frightened, the nine lower stripes became white, and three white-pink vertical bands appeared from the pectoral fin region to the anal fin region. The last band was wider than the other two, beginning at the anal fin and continuing to the end of the caudal peduncle. The lower sides, belly and breast were shine-white. The snout and top of the head were dark red, with the upper portion of the maxilla and the vertical branch of the preopercular bone white. It showed a white streak diagonally across the cheek, from the upper jaw to the preopercular spine. The lower jaw was white but the lower lip was red. The iris was bright red near the pupil, the distal margin blackish. The dorsal fin spines were yellowish or yellowish-green, but the interspinal membranes were white after the spine, and yellowish-green just before the next spine. The soft dorsal fin rays were pink with the membrane showing an intermediate dark vertical line between rays. The outer caudal fin

TABLE 1. - Morphometric (in $\mathrm{mm}$ ) and meristic data of the specimen of Holocentrus ascensionis caught in Gran Canaria Island.

\begin{tabular}{lr} 
Total length & 205.0 \\
Fork length & 170.3 \\
Standard length & 162.0 \\
Head length & 47.9 \\
Eye diameter & 14.9 \\
Base of the anterior portion of the dorsal fin & 68.6 \\
Base of the posterior portion of the dorsal fin & 26.4 \\
Base of anal fin & 24.8 \\
Predorsal distance (anterior portion) & 21.5 \\
Predorsal distance (posterior portion) & 116.5 \\
Prepectoral distance & 52.9 \\
Preanal distance & 119.0 \\
Prepelvic distance & 56.2 \\
Pectoral length & 32.2 \\
Pelvic length & 37.2 \\
Body depth & 52.9 \\
& \\
Fin rays & \\
$\quad$ Dorsal & XI+16 \\
$\quad$ Pectoral & 13 \\
Anal & IV+10 \\
Scales in the lateral-line & 51 \\
\hline
\end{tabular}

rays were white (the rest pink). The first three anal spines were white and the fourth spine and soft rays were pink. The pectoral fins were pink, but the upper edge of the first rays were darker red. Pelvic fin spine and anterior margin of first ray were white, while the other pelvic fin rays were pink.

When caugth the squirrelfish produced sounds, a behavior that was also reported by Moulton (1958) in the Bimini area (Central-west Atlantic). During housing, the fish was fed with pelletized food used for feeding fish in aquaculture.

This record supports the comments made by Greenfield (1981) who indicated that possibly the geographical distribution of this species was more wide-spread along the African coast. In the Western Atlantic, this species occurs from North Carolina (USA) to Santos (Brazil) (Greenfield, 1981; BenTuvia, 1990), and probably in the Eastern Atlantic it has a similar latitudinal distribution (from Angola to Canary Islands, at least). Possibly, its populations are scarce north of the equator or it is confused with Adioryx hastatus or Myripristis jacobus and catch is reported as red squirrelfish, as suggested by Robins et al. (1986) in the West Atlantic, where it is included in market shipments of red snapper.

\section{ACKNOWLEDGEMENTS.}

Our thanks to the Fishermen's Association of Castillo del Romeral (Gran Canaria) for making possible this new record of the ichthyofauna of the Canary Islands. Thanks are also given to Dr. Teresa Moreno for her assistance with the photographic material.

\section{REFERENCES}

Ben-Tuvia, A. - 1990. Holocentridae. In: Quéro, J.C., J.C. Hureau, C. Karrer, A. Post and L. Saldanha. Check-list of Fishes of the Eastern Tropical Atlantic. Vol. II. pp:627-628. Junta Nacional de Investigação Científica e Tecnológica. Lisbon.

Greenfield, D.W. - 1981. Holocentridae. In: Fischer, W.G., G. Bianchi and W.B. Scott. FAO Species Identification Sheets for Fishery Purposes. Eastern Central Atlantic; fishing Areas 34, 47 (in part). Canada Funds-in-Trust. Ottawa, Department of Fisheries and Oceans Canada, by arrangement with the Food and Agriculture Organization of the United Nations. Vol. II.

Hernández-García, V., J.L. Hernández-López and J.J. Castro. 1998. The octopus (Octopus vulgaris) in the small-scale trap fishery off the Canary Islands (Central-East Atlantic). Fish. Res., 35: 183-189.

Moulton, J.M. - 1958 The acoustical behavior of some fishes in the Bimini area. Biol. Bull., 114: 357-374.

Robins, C.R., G.C. Ray, J. Douglass and R. Freund. - 1986. A field guide to Atlantic coast fishes of North America. The Peterson Field Guide Series. Houghton Mifflin Company. Boston.

Scient. ed.: M. Harmelin-Vivien 